\title{
Human macrophages limit oxidation products in low density lipoprotein
}

\author{
Lillemor Mattsson Hultén ${ }^{* 1}$, Christina Ullström ${ }^{1}$, Alexandra Krettek1, \\ David van Reyk ${ }^{2}$, Stefan L Marklund ${ }^{3}$, Claes Dahlgren ${ }^{4}$ and Olov Wiklund ${ }^{1}$
}

\begin{abstract}
Address: ${ }^{1}$ Wallenberg Laboratory for Cardiovascular Research, Sahlgrenska University Hospital, SE-413 45 Göteborg, Sweden, ${ }^{2}$ Department of Health Sciences, University of Technology, Sydney, N.S.W. 2007, Australia, ${ }^{3}$ Medical Biosciences, Clinical Chemistry, Umeå University Hospital, SE-901 85 Umeå, Sweden and ${ }^{4}$ Phagocyte Research Laboratory, Department of Rheumatology and Inflammation Research, University of Göteborg, SE-413 46 Göteborg, Sweden

Email: Lillemor Mattsson Hultén* - Lillemor.Mattsson@wlab.gu.se; Christina Ullström - Christina.Ullstrom@wlab.gu.se; Alexandra Krettek - Alexandra.Krettek@wlab.gu.se; David van Reyk - David.VanReyk@uts.edu.au;

Stefan L Marklund - stefan.marklund@medbio.umu.se; Claes Dahlgren - Claes.Dahlgren@microbio.gu.se; Olov Wiklund - Olov.Wiklund@wlab.gu.se

* Corresponding author
\end{abstract}

Published: 04 March 2005

Lipids in Health and Disease 2005, 4:6 doi:10.1186/1476-5IIX-4-6

This article is available from: http://www.lipidworld.com/content/4/I/6

(C) 2005 Hultén et al; licensee BioMed Central Ltd.

This is an Open Access article distributed under the terms of the Creative Commons Attribution License (http://creativecommons.org/licenses/by/2.0), which permits unrestricted use, distribution, and reproduction in any medium, provided the original work is properly cited.
Received: II February 2005

Accepted: 04 March 2005

\begin{abstract}
This study tested the hypothesis that human macrophages have the ability to modify oxidation products in LDL and oxidized LDL (oxLDL) via a cellular antioxidant defence system. While many studies have focused on macrophage LDL oxidation in atherosclerosis development, less attention has been given to the cellular antioxidant capacity of these cells.

Compared to cell-free controls $(6.2 \pm 0.7 \mathrm{nmol} / \mathrm{mg} \mathrm{LDL})$, macrophages reduced TBARS to $4.42 \pm$ $0.4 \mathrm{nmol} / \mathrm{mg}$ LDL after $24 \mathrm{~h}$ incubation with LDL $(P=0.022)$. After $2 \mathrm{~h}$ incubation with oxLDL, TBARS were $3.69 \pm 0.5 \mathrm{nmol} / \mathrm{mg} \mathrm{LDL}$ in cell-free media, and $2.48 \pm 0.9 \mathrm{nmol} / \mathrm{mg} \mathrm{LDL}$ in the presence of macrophages $(P=0.034)$. A reduction of lipid peroxides in LDL $(33.7 \pm 6.6 \mathrm{nmol} / \mathrm{mg}$ $\mathrm{LDL})$ was found in the presence of cells after $24 \mathrm{~h}$ compared to cell-free incubation ( $105.0 \pm$ I4. I $\mathrm{nmol} / \mathrm{mg} L D L)(P=0.005)$. The levels of lipid peroxides in oxLDL were $137.9 \pm 59.9 \mathrm{nmol} / \mathrm{mg} L D L$ and in cell-free media $242 \pm 60.0 \mathrm{nmol} / \mathrm{mg} \operatorname{LDL}(P=0.012)$. Similar results were obtained for hydrogen peroxide. Reactive oxygen species were detected in LDL, acetylated LDL, and oxLDL by isoluminol-enhanced chemiluminescence $(\mathrm{CL})$. Interestingly, oxLDL alone gives a high $\mathrm{CL}$ signal. Macrophages reduced the $C L$ response in oxLDL by $45 \%(P=0.0016)$. The increased levels of glutathione in oxLDL-treated macrophages were accompanied by enhanced catalase and glutathione peroxidase activities.

Our results suggest that macrophages respond to oxidative stress by endogenous antioxidant activity, which is sufficient to decrease reactive oxygen species both in LDL and oxLDL. This may suggest that the antioxidant activity is insufficient during atherosclerosis development. Thus, macrophages may play a dual role in atherogenesis, i.e. both by promoting and limiting LDLoxidation.
\end{abstract}




\section{Introduction}

Oxidative modification of low density lipoprotein (LDL) plays a major role in the pathogenesis of atherosclerosis. The first stage of atherogenesis is characterized by an influx and accumulation of LDL in the intima, followed by recruitment of blood-derived monocytes and lymphocytes to the developing lesion [1]. Subsequently, LDL is oxidatively modified by free radicals that are either secreted from cells within lesions or generated extracellular in the arterial wall [2]. Oxidatively modified LDL (oxLDL) induces a multitude of cellular responses which lead to vascular dysfunction [3]. Much attention has sofar been devoted to the mechanisms by which cells oxidize LDL, since interventions targeting these mechanisms could prevent or retard the disease process.

However, cells may also provide a protective effect by reducing oxidation products present in LDL and oxLDL. Murine macrophages effectively block LDL oxidation by mechanisms which include metal ion sequestration [4]. Recent studies show that macrophages decrease cholesteryl ester hydroperoxide levels in LDL, an antioxidant action that is proportional to cell number $[5,6]$. In addition, endothelial cells prevent accumulation of lipid hydroperoxides in LDL [7]. Human hepatic cells show a protective role by selective uptake and detoxification of cholesterol ester hydroperoxides present in high density lipoprotein [8]. Enzymes associated with antioxidant defense, such as manganese superoxide dismutases, catalase, and glutathione peroxidases are induced by oxidants in vitro [9-11].

Four selenium-dependent glutathione peroxidases (GPx) have been identified sofar: cytosolic GPx (cGPx), gastrointestinal GPx (GI-GPx), plasma GPx (pGPx), and phospholipid hydroperoxide GPx (PHGPx) [12,13]. The PHGPx reduces hydroperoxides present in complex lipids such as phospholipids and cholesteryl esters [14,15]. Interestingly, increased glutathione levels are present in macrophages derived from the human monocytic cell line THP-1, as well as in mouse peritoneal macrophages after incubation with oxLDL $[16,17]$. An increased activity of both glutathione peroxidase and superoxide dismutase occurs in the arterial wall of cholesterol-fed rabbits [18]. Furthermore, lipid-laden macrophages within atherosclerotic vessels express an extracellular form of superoxide dismutase (EC-SOD) [19].

This study tested the hypothesis that human macrophages have the ability to modify oxidation products in LDL and oxLDL. We also analyzed the activity of cellular antioxidant defenses such as catalase, glutathione peroxidase, and superoxide dismutase in these cells. We used early macrophages as cell culture model to mimic newly recruited macrophages into the intima.

\section{Materials and methods Cell isolation}

Mononuclear cells were isolated by the Ficoll-Hypaque procedure (Pharmacia, Uppsala, Sweden) [20] from buffy coats obtained from the blood of healthy donors from the Blood Bank at Sahlgrenska University Hospital, Göteborg. Monocytes in RPMI 1640 medium (Life Technologies, Paisley, Scotland), supplemented with non-essential amino acids, $2 \mathrm{mM}$ sodium pyruvate, $100 \mathrm{U} / \mathrm{mL}$ penicillin, and $100 \mu \mathrm{g} / \mathrm{mL}$ streptomycin were seeded in 6 well plates at $4 \times 10^{6}$ cells per well. Non-adherent cells were removed after $1 \mathrm{~h}$. RPMI 1640 containing $100 \mu \mathrm{g} / \mathrm{mL}$ LDL or oxLDL was incubated at $37^{\circ} \mathrm{C}$ in $5 \% \mathrm{CO}_{2}$ in the presence or absence of macrophages. By definition, monocytes are denoted macrophages when they are attached, thus the cells used in this study are considered early human monocyte-derived macrophages (HMDM).

For chemiluminescence experiments, monocytes were allowed to adhere to cell culture flasks for $1 \mathrm{~h}$. Adhered macrophages were then detached by incubation with PBS containing $5 \mathrm{mM}$ EDTA and $2 \%$ fetal calf serum for 20 minutes at $+4^{\circ} \mathrm{C}$ [21]. Cells were collected, washed, and resuspended to a density of $5 \times 10^{6}$ cells $/ \mathrm{mL}$ in KrebsRinger Bicarbonate buffer supplemented with glucose (KRG) (Sigma, St. Louis, Missouri). To obtain non-viable macrophages, cells were stored at $+4^{\circ} \mathrm{C}$ for $16 \mathrm{~h}$. Trypan blue exclusion test confirmed that $100 \%$ of the cells were non-viable.

\section{Lipoproteins}

Fresh human EDTA-plasma was obtained from healthy male donors after overnight fasting. LDL (density 1.019$1.063 \mathrm{~g} / \mathrm{L}$ ) was isolated by sequential ultracentrifugation [22]. Before oxidation, native LDL was desalted on a PD10 column equilibrated with PBS containing $100 \mu \mathrm{g} / \mathrm{mL}$ penicillin and $100 \mu \mathrm{g} / \mathrm{ml}$ streptomycin (PEST) using PBSPEST as elution buffer. The LDL was oxidized at $37^{\circ} \mathrm{C}$ for 2-24 hours by $12.5 \mu \mathrm{mol} \mathrm{CuSO} / 4 / \mathrm{mg} \mathrm{LDL}$. Oxidation was terminated through the addition of $0.5 \mathrm{mmol} / \mathrm{L}$ EDTA. The oxLDL was purified on a PD-10 column with PBS as elution buffer and sterilized by filtration through a 0.22 $\mu \mathrm{m}$ filter. Native LDL was acetylated as described [23]. Oxidation of LDL was determined as the relative electrophoretic mobility (REM), i.e. the ratio between the distance oxLDL and native LDL migrate on a $0.5 \%$ agarose gel. The LDL in this study was oxidized for $2 \mathrm{~h}$ and had a REM ranging from 1.06 to 1.32 and TBARS values between 3 and $8 \mathrm{nmol} \mathrm{MDA} / \mathrm{mg}$ LDL protein. Lipoprotein concentrations were determined with the BioRad protein assay using $\gamma$-globulin as standard.

\section{Chemiluminescence}

The chemiluminescence (CL) assay was performed at $37^{\circ} \mathrm{C}$ and the $\mathrm{CL}$ detected for at least 100 minutes with a 
luminescence counter (Bio Orbit Luminometer 1251, Turku, Finland) [21]. The CL response was detected in a total volume of $1.0 \mathrm{~mL}$, containing $10 \mu \mathrm{g}$ isoluminol (Sigma), $4 \mathrm{U}$ horseradish peroxidase (Roche AB, Stockholm, Sweden), and $100 \mu \mathrm{g}$ of either LDL, oxLDL, or acLDL in KRG in the presence or absence of $5 \times 10^{5}$ cells. As a specific inhibitor of hydrogen peroxide, $30 \mu \mathrm{g}$ catalase (Roche $\mathrm{AB}$ ) was added in some experiments to oxLDL without cells.

\section{Measurement of oxidation products}

Thiobarbituric acid-reactive substances (TBARS) were determined by the method of Yagi [24]. Fluorescence was measured at $553 \mathrm{~nm}$ with $515 \mathrm{~nm}$ excitation. Lipid peroxides (LPO) were determined by the Lipohydrox assay from Wak-Chemie Medical (Bad-Soden, Germany). Lipid peroxides are reduced to hydroxyl derivatives in the presence of hemoglobin, and the chromogen 10-N-methylcarbamyl-3, 7-dimethylamino-10H-phentiazine is oxidatively cleaved to form methylene blue. Lipid peroxides are quantitated by colorimetric measuring of the methylene blue at $675 \mathrm{~nm}$.

Levels of hydrogen peroxide equivalents $\left(\mathrm{H}_{2} \mathrm{O}_{2 e q}\right)$ were analyzed in the LDL-containing media incubated with or without macrophages. The assay is based on the oxidation of ferrous ions to ferric ions by hydrogen peroxide at acidic pH (OXIS International Inc., Portland, Oregon). The ferric ion binds to the indicator dye xylenol-orange to form a stable complex which is measured at $560 \mathrm{~nm}$.

Apolipoprotein B (Apo B) concentration was determined in cell culture media by immunoprecipitation enhanced by polyethylene glycol at $340 \mathrm{~nm}$ (Thermo Clinical Labsystems, Espoo, Finland). ApoB analyses were performed on a Konelab 20 autoanalyser (Thermo Clinical Labsystems).

\section{Analysis of antioxidant properties of macrophages}

The intracellular levels of glutathione and the activity of GPx were measured in crude extracts from macrophages incubated with either LDL or oxLDL. The cells were washed twice with ice-cold PBS and harvested in $0.5 \mathrm{~mL}$ lysis buffer. For glutathione peroxidase measurements, this buffer contained $50 \mathrm{mM}$ Tris- $\mathrm{HCl}, \mathrm{pH} 7.5,5 \mathrm{mM}$ EDTA, $1 \mathrm{mM}$ dithiothreitol. For glutathione measurements, the cells were lysed in $0.5 \mathrm{~mL}$ ice-cold 5\% metaphosphoric acid. The lysate was spun down at $3000 \times \mathrm{g}$, and the supernatants stored at $-80^{\circ} \mathrm{C}$.

The presence of glutathione peroxidase was determined with a colorimetric assay (Bioxytech GPX-340) and glutathione (GSH) was measured with Bioxytech GSH-400, both from OXIS International Inc. The assay GPX-340 measures the functional activity of the GPx. In functional terms, all four types of GPx (cGPx, GI-GPx, pGPx, and PHGPx) appear similar in catalytic activity [12,25].

$\mathrm{ROOH}+2 \mathrm{GSH}$----GPx$---->\mathrm{ROH}+\mathrm{GSSG}$ (oxidized glutathione)+ $\mathrm{H} 2 \mathrm{O}$

GSSG + NADPH+ + $\mathrm{H}^{+}------->>$2GSH + NADP+

Catalase activity in macrophages was quantified by the method of Aebi [26]. Decomposition of $\mathrm{H}_{2} \mathrm{O}_{2}$ was measured in cell lysates at $240 \mathrm{~nm}$. One unit of catalase activity was defined as the rate constant for the reaction using purified catalase (Roche $\mathrm{AB}$ ) as standard.

In the cell lysates, the CuZn-superoxide dismutase (SOD) and Mn-SOD enzymatic activities were measured with a direct spectrophotometric method [27]. Extracellular SOD protein was determined by ELISA essentially as previously described [28].

\section{Data analyses}

Data were expressed as means \pm standard error. Statistical analysis was performed using Student's paired t-test or ANOVA. $\mathrm{P}$ values $<0.05$ were considered statistically significant.

\section{Results \\ Macrophages diminish oxidation products in LDL and oxLDL}

To study the effect of macrophages on LDL oxidation, we measured TBARS, LPO, and $\mathrm{H}_{2} \mathrm{O}_{2}$ in LDL-containing culture media after $2 \mathrm{~h}$ and $24 \mathrm{~h}$ incubation with or without macrophages.

Compared to cell-free controls $(6.2 \pm 0.7 \mathrm{nmol} / \mathrm{mg} \mathrm{LDL})$, there was a significant reduction of TBARS by macrophages to $4.42 \pm 0.4 \mathrm{nmol} / \mathrm{mg}$ LDL after $24 \mathrm{~h}$ incubation with LDL $(P=0.022)$ (Fig. 1A). After $2 \mathrm{~h}$ incubation with oxLDL, TBARS was $3.69 \pm 0.5 \mathrm{nmol} / \mathrm{mg}$ LDL in cell free media, and $2.48 \pm 0.9 \mathrm{nmol} / \mathrm{mg}$ LDL in the presence of macrophages $(P=0.034)$. Although a time-dependent increase of TBARS in the presence of cells is seen, this change was not statistically significant. Lipid peroxide levels are unaffected in LDL and oxLDL incubated in cell-free wells during $2 \mathrm{~h}$ to $24 \mathrm{~h}$ (Fig. 1B). In the presence of cells, a reduction of lipid peroxides in LDL $(33.7 \pm 6.6 \mathrm{nmol} / \mathrm{mg}$ LDL) was found after $24 \mathrm{~h}$ compared to cell-free incubation $(105.0 \pm 14.1 \mathrm{nmol} / \mathrm{mg} \mathrm{LDL})(\mathrm{P}=0.005)$. In oxLDL, the cell-mediated loss of lipid peroxides was significant compared to cell-free media after $24 \mathrm{~h}$. The levels of lipid peroxides in oxLDL were $137.9 \pm 59.9 \mathrm{nmol} / \mathrm{mg} \mathrm{LDL}$ and in cell-free media $242 \pm 60.0 \mathrm{nmol} / \mathrm{mg} \operatorname{LDL}(\mathrm{P}=0.012)$. In LDL-containing media incubated in cell-free wells, the levels of $\mathrm{H}_{2} \mathrm{O}_{2 \mathrm{eq}}$ increase with time from $116 \pm 31 \mathrm{nmol} /$ $\mathrm{mg}$ LDL after $2 \mathrm{~h}$, to $270 \pm 46 \mathrm{nmol} / \mathrm{mg}$ LDL after $24 \mathrm{~h}(\mathrm{P}$ 

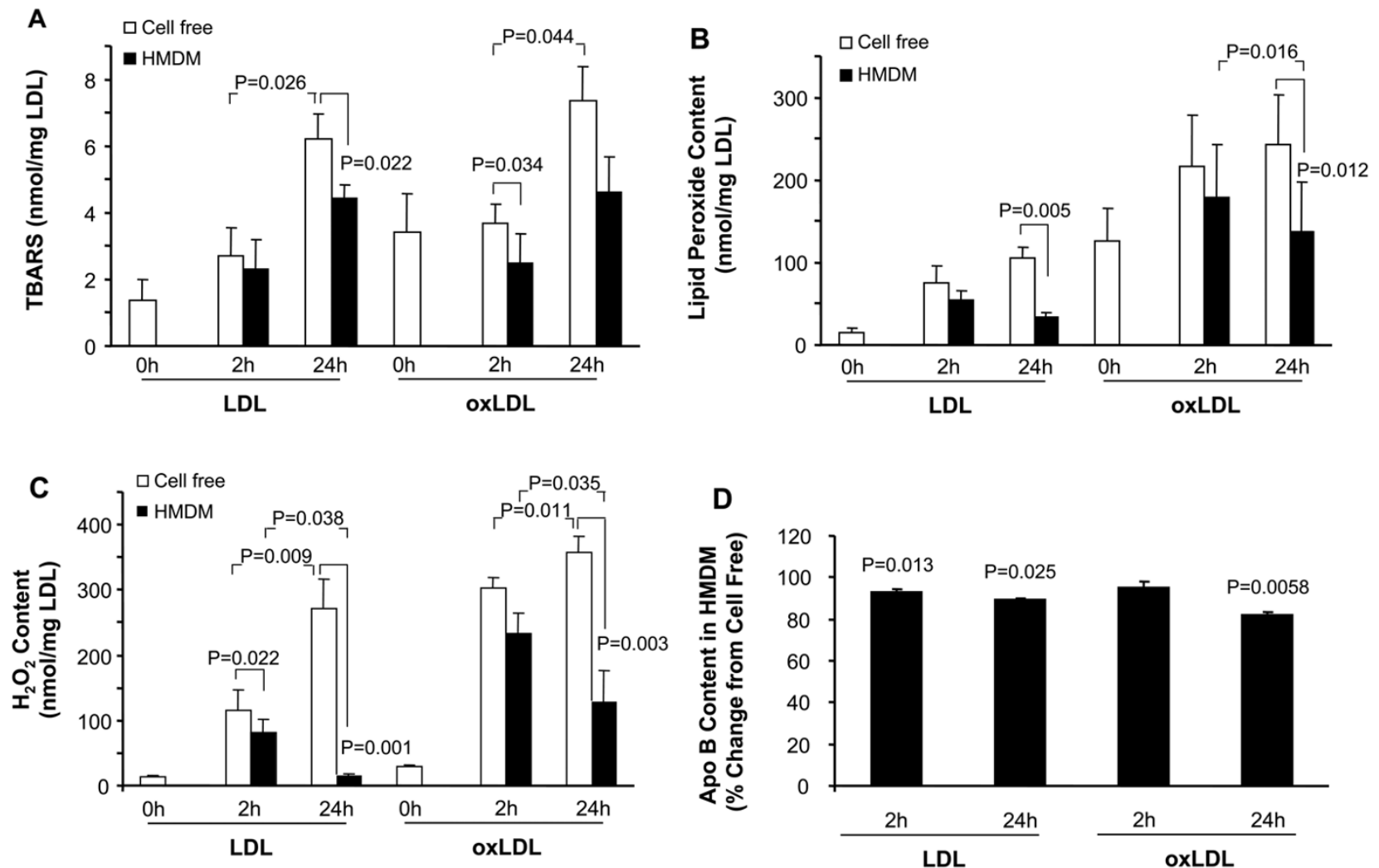

Figure I

Effect of macrophages on oxidation products in LDL and oxLDL. RPMI 1640 containing $100 \mu g / \mathrm{mL}$ of LDL or oxLDL (oxidized for $2 \mathrm{~h}$ ) was incubated in cell culture wells at $37^{\circ} \mathrm{C}$ with and without macrophages (HMDM) for $2 \mathrm{~h}$ and $24 \mathrm{~h}$. Values are expressed as nmol/mg LDL, TBARS $(n=5)(A)$, lipid peroxides $(n=6)(B), \mathrm{H}_{2} \mathrm{O}_{2}(n=6),(C)$. Values of Apo B are expressed as \% change compared to cell free control incubations $(n=4)(D)$.

$=0.009$ ) (Fig. 1C). Levels of $\mathrm{H}_{2} \mathrm{O}_{2 \text { eq }}$ increase from $303 \pm$ $14 \mathrm{nmol} / \mathrm{mg}$ LDL to $357 \pm 24 \mathrm{nmol} / \mathrm{mg}$ LDL in oxLDLcontaining media $(\mathrm{P}=0.011)$, suggesting both LDL and oxLDL are oxidized during culture conditions. $\mathrm{H}_{2} \mathrm{O}_{2 \mathrm{eq}}$ is significantly decreased in both $\operatorname{LDL}(\mathrm{P}=0.038)$ and oxLDL $(\mathrm{P}=0.035)$ after incubation with macrophages. In macrophage-treated LDL, the $\mathrm{H}_{2} \mathrm{O}_{2 \text { eq }}$ content is decreased to $14.8 \pm 2.9 \mathrm{nmol} / \mathrm{mg}$ LDL after $24 \mathrm{~h}$, which is similar to levels found in non-treated LDL $(0 \mathrm{~h})$. Taken together, these results suggest a cell-mediated loss of oxidation products in both LDL and oxLDL in the presence of macrophages.

Apo B was analysed to study if the cell mediated decrease in oxidation products was due to a decrease of LDL or oxLDL in the cell culture media. In the presence of macrophages, the content of apo $\mathrm{B}$ in native LDL is reduced by $7 \%$ after $2 \mathrm{~h}(\mathrm{P}=0.013)$ and $11 \%$ after $24 \mathrm{~h}(\mathrm{P}=0.025)$
(Fig. 1D). In the oxLDL medium, no significant change of apo $B$ in the medium is found after $2 \mathrm{~h}$, and the content of apo B in oxLDL decreases $18 \%$ after $24 \mathrm{~h}$ incubation with macrophages compared to cell-free control $(\mathrm{P}=$ $0.006)$. This result suggests that the decrease in oxidation products can not be fully explained by an increased uptake of LDL or oxLDL by macrophages.

To further test the capacity of macrophages to decrease oxidation products in LDL, we used isoluminol-enhanced chemiluminescence to detect reactive oxygen species in LDL. OxLDL, acLDL, or LDL was incubated with macrophages $\left(5 \times 10^{5}\right.$ cells $)$ or without cells at $37^{\circ} \mathrm{C}$. OxLDL alone had a CL response of approximately $400 \mathrm{mV}$ after 2 h (Fig. 2). AcLDL shows a low but increasing CL up to 30 $\mathrm{mV}$ after $2 \mathrm{~h}$ as does native LDL, but the response is lower than that of oxLDL. In repeated experiments, incubation of macrophages with oxLDL leads to a significant 


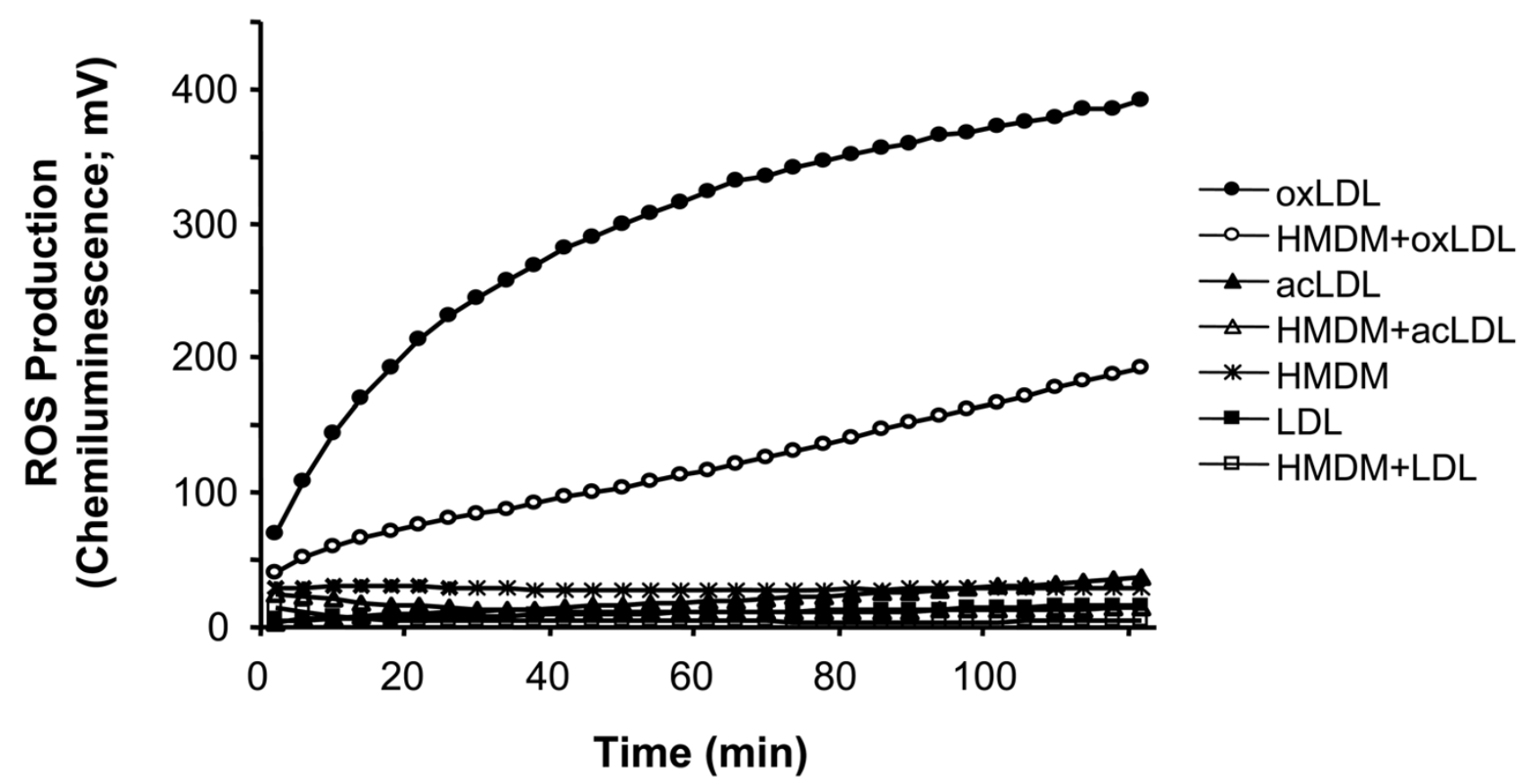

Figure 2

Production of reactive oxygen species from LDL, oxLDL and macrophages as measured by isoluminolenhanced chemiluminescence. The incubation mixture of $1.0 \mathrm{~mL} \mathrm{KRG}$ contained $5 \times 10^{5}$ cells (HMDM), $10 \mu \mathrm{g}$ isoluminol, $4 \mathrm{U}$ horseradish peroxidase, and $100 \mu \mathrm{g}$ of LDL, oxLDL (oxidized for $2 \mathrm{~h}$ ), or acLDL. The chemiluminescence was measured every 2 minutes for a total of 100 minutes at $37^{\circ} \mathrm{C}(n=5)$.

reduction in the maximum peak value to $260 \pm 45 \mathrm{mV}$ compared to $462 \pm 127 \mathrm{mV}$ for oxLDL alone $(\mathrm{P}<0.01)(\mathrm{n}$ $=6$ ). Adding catalase to oxLDL leads to a decrease of the CL signal by $37 \%$, suggesting peroxides in the oxLDL.

LDL oxidized by $\mathrm{Cu}^{2+}$ for 2,8 , or $20 \mathrm{~h}$, shows similar maximum peak values, however a lag time of $10 \mathrm{~min}$ is observed with the shorter oxidation times. Incubation of oxLDL with macrophages leads to a reduction in the CL signal (Fig. 3). Different dilutions of oxLDL lead to a dose dependent increase in CL (Fig. 4). The addition of macrophages results in a $45 \%$ lower CL maximal peak value at the different concentrations of oxLDL $(P=0.0016)$.

To exclude the possibility that quenching contributes to the macrophage effect, oxLDL was incubated with nonviable macrophages. No reduction in CL signal is seen (Fig. 5), which suggests that no quenching occurred and that viable cells are necessary for antioxidative activity.

\section{LDL affects cellular antioxidant defences in macrophages} Since the levels of peroxides are elevated in oxLDL compared to LDL, and the cellular defences against peroxides excess are catalase and GPx, we investigated the cellular activity of these enzymes in macrophages. Macrophages incubated with oxLDL for $2 \mathrm{~h}$ have increased intracellular activity of catalase $(P=0.006)$ and GPx $(P=0.0002)$ (Figs $6 \mathrm{~A}$ and $6 \mathrm{~B})$. In contrast, no significant increase of the intracellular activity of these enzymes occurs in macrophages incubated with LDL. In addition, the expression of glutathione, which is a cofactor for the GPx enzymes when $\mathrm{H}_{2} \mathrm{O}_{2}$ is detoxified, is enhanced in macrophages treated with oxLDL for $2 \mathrm{~h}(\mathrm{P}=0.0048)$ (Fig. 6C).

Neither LDL nor oxLDL significantly affect the CuZn-SOD or Mn-SOD activity in macrophages (Table I). However, the Mn-SOD activity is enhanced after $24 \mathrm{~h}$ compared to $2 \mathrm{~h}$ incubations. Although an increase in secreted EC-SOD is seen at $24 \mathrm{~h}$, this change was not statistically significant. Neither LDL nor oxLDL affect this secretion. These observations suggest that macrophages respond to oxLDL by increasing their enzyme activity of catalase and glutathione peroxidase.

\section{Discussion}

Oxidation of LDL is a crucial event in the pathophysiology of atherosclerosis. Reactive oxygen species such as $\mathrm{H}_{2} \mathrm{O}_{2}$ participate in the oxidation of LDL [29]. Although the 


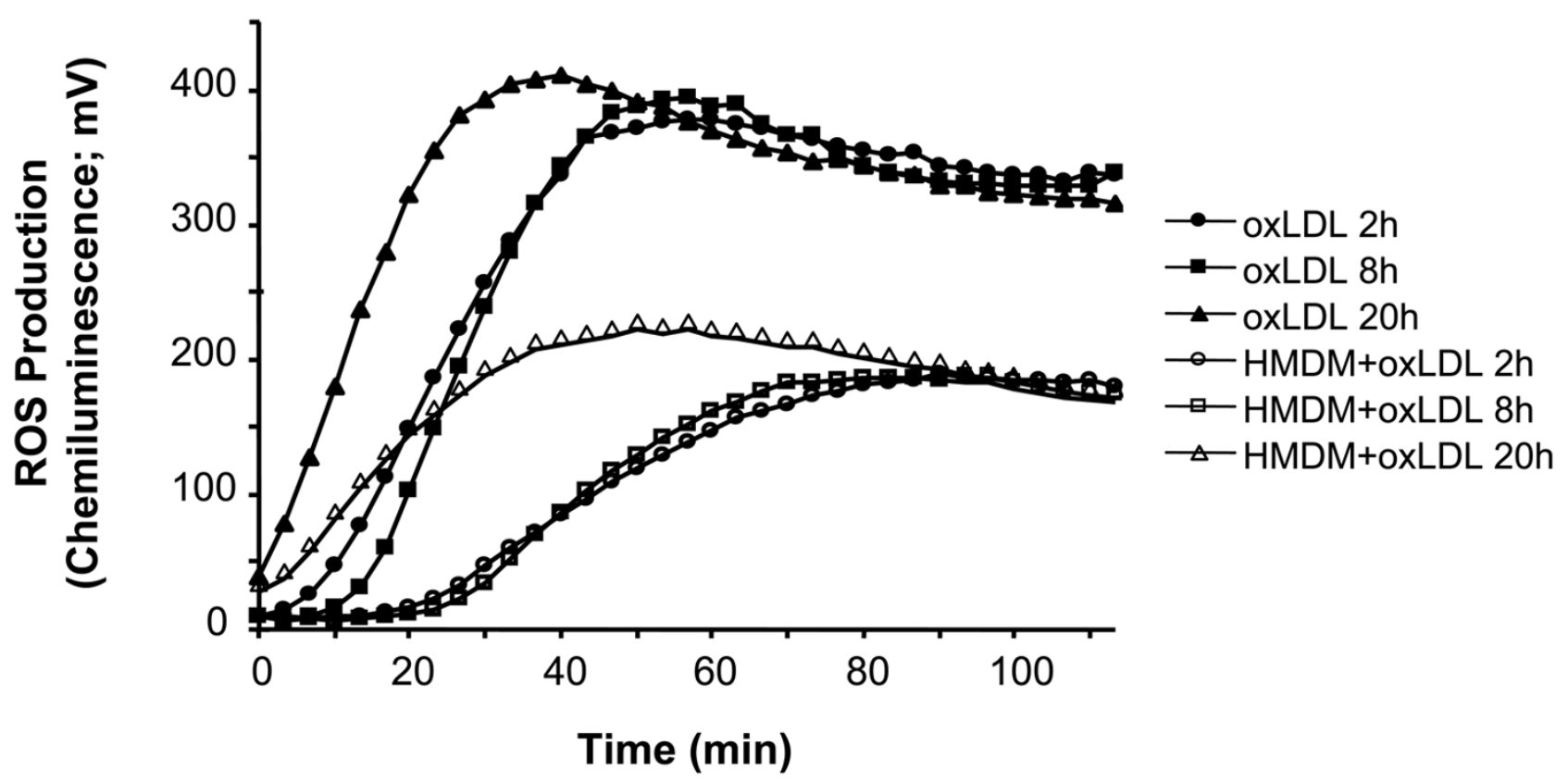

Figure 3

Production of reactive oxygen species from oxLDL and macrophages as measured by isoluminol-enhanced chemiluminescence. The incubation mixture of $1.0 \mathrm{~mL} \mathrm{KRG}$, containing $10 \mu \mathrm{g}$ isoluminol, $4 \mathrm{U}$ horseradish peroxidase, and $100 \mu \mathrm{g}$ of oxLDL (oxidized for either $2 \mathrm{~h}, 8 \mathrm{~h}$ or $20 \mathrm{~h}$ ), was used alone or in combination with $5 \times 10^{5}$ macrophages (HMDM) $(n=3)$.

mechanisms are not fully understood, aortic cells such as endothelial cells, smooth muscle cells, and macrophages have the capacity to oxidize LDL in vitro. We have recently shown that hypoxia enhances both macrophage-mediated LDL oxidation and the expression of the putative LDL-oxidizing enzyme 15-lipoxygenase-2 [30]. While many studies have focused on cellular oxidation of LDL, less attention has been given to the cellular antioxidant capacity of macrophages.

This study shows that macrophages play an important role in limiting lipid oxidation products that accumulate in LDL and oxLDL. Since early macrophages are used in this study, this may resemble newly recruited macrophages entering into the arterial intima. Regarding oxLDL, macrophages decrease TBARS levels by about 30\%, LPO decreases $43 \%$, and the $\mathrm{H}_{2} \mathrm{O}_{2 \text { eq }}$ content decreases $64 \%$ in cell culture media after $24 \mathrm{~h}$ compared to cell-free controls. These results are in agreement with an earlier study where human macrophages reduce the content of cholesteryl ester hydroperoxides in LDL by $43 \%$ [5]. When the apo B content was analyzed in the culture media, we found that the levels of apo B in oxLDL were $18 \%$ reduced after $24 \mathrm{~h}$ incubation with macrophages compared to cell free control. For LDL the corresponding figure was 11\%, which implies that the decrease in oxidation products cannot be entirely explained by a higher uptake of LDL or oxLDL by macrophages. Our results suggest that macrophages respond to oxidative stress by an endogenous antioxidative activity, which is sufficient to decrease reactive oxygen species; i.e. TBARS, LPO and $\mathrm{H}_{2} \mathrm{O}_{2}$ both in LDL and oxLDL. Our data also suggest that oxidation products accumulate in LDL and in oxLDL during regular cell culture conditions in the absence of cells. This has to be taken into consideration when cell culture data using LDL are interpreted.

The chemiluminescence technique is generally used to detect cellular ROS production. The amplifying molecule isoluminol reacts with ROS to produce an excited state intermediate that emits light upon relaxation to the ground state [31]. Our data show that oxLDL contains reactive oxygen metabolites that have the capacity to induce CL. Lipid hydroperoxides, the major oxidizing species in oxLDL, are likely to cause the CL. In the presence of transition metal ions, they generate Fenton-type oxidants, which may induce the chemiluminescence. The CL response is reduced when LDL is oxidized longer than 24 $\mathrm{h}$. This agrees with previous data concerning the kinetics of LDL oxidation where lipid hydroperoxides are formed 


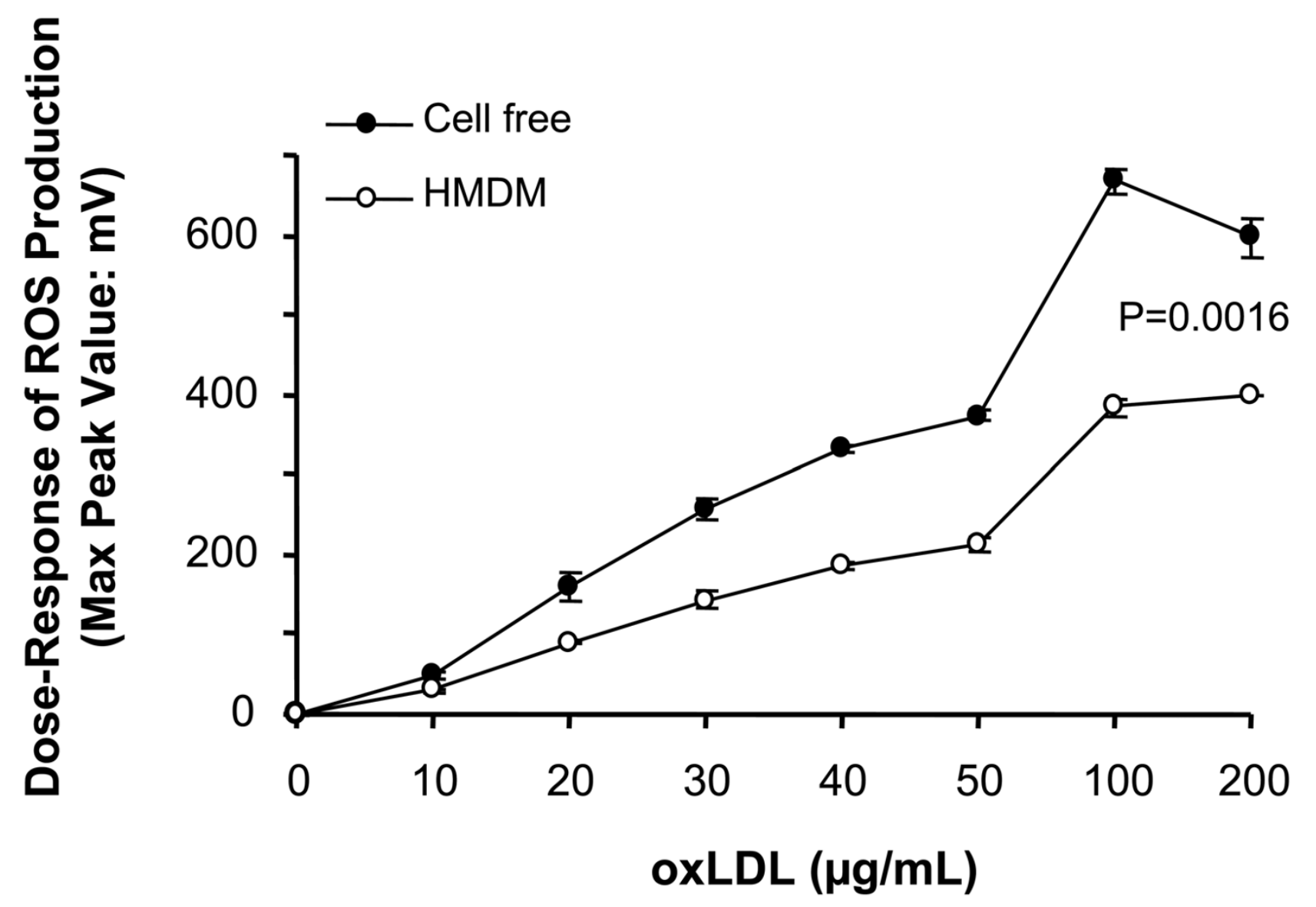

Figure 4

Dose-response effect of oxLDL on production of reactive oxygen species as measured by isoluminol-enhanced chemiluminescence. The incubation mixture of $1.0 \mathrm{ml} \mathrm{KRG}$ contained $10 \mu \mathrm{g}$ isoluminol, and different concentrations of oxLDL oxidized for $2 \mathrm{~h}$, alone and in combination with HMDM $\left(5 \times 10^{5}\right.$ cells). Data are shown as means of maximal peak values in $\mathrm{mV} \pm \mathrm{SE}$ for triplicate determinations within a single experiment and are representative of two independent experiments. Results of oxLDL in cell-free incubations versus oxLDL in the presence of macrophages were analyzed by ANOVA.

during the propagation phase and are decreased during the decomposition phase [32]. In the presence of macrophages, the CL response in oxLDL is reduced by $45 \%$, which suggests that these cells exhibit antioxidant activity. Our results further suggest that cellular viability is necessary for antioxidant activity.

There are a number of cellular defences against oxidative stress, such as superoxide dismutase, catalase, and glutathione-related enzymes. In this study we sought to define the antioxidative activity of macrophages. All glutathione peroxidases reduce $\mathrm{H}_{2} \mathrm{O}_{2}$ or soluble alkyl peroxides, by coupling its reduction of $\mathrm{H}_{2} \mathrm{O}$ with oxidation of glutathione [11]. We found increased glutathione peroxidase activity that coincided with enhanced glutathione levels in oxLDL-treated macrophages. Only PHGPx reduces hydroperoxy groups of lipids together with those of phospholipids and cholesteryl esters when present in lipoproteins [15]. Interestingly, overexpression of PHGPx inhibits $\mathrm{H}_{2} \mathrm{O}_{2}$-induced oxidation and activation of $\mathrm{NFKB}$ in transfected rabbit smooth muscle cells [33]. Our results may have in vivo relevance, since an increased activity of glutathione peroxidase is found in the artery wall of cholesterol-fed rabbits [18].

Catalase is a representative antioxidant enzyme and previous studies show that oxidants such as $\mathrm{H}_{2} \mathrm{O}_{2}$ and lipid peroxides induce catalase gene expression in cultured rabbit endothelial cells, rabbit macrophages, and human smooth muscle cells [10]. This study provides further 


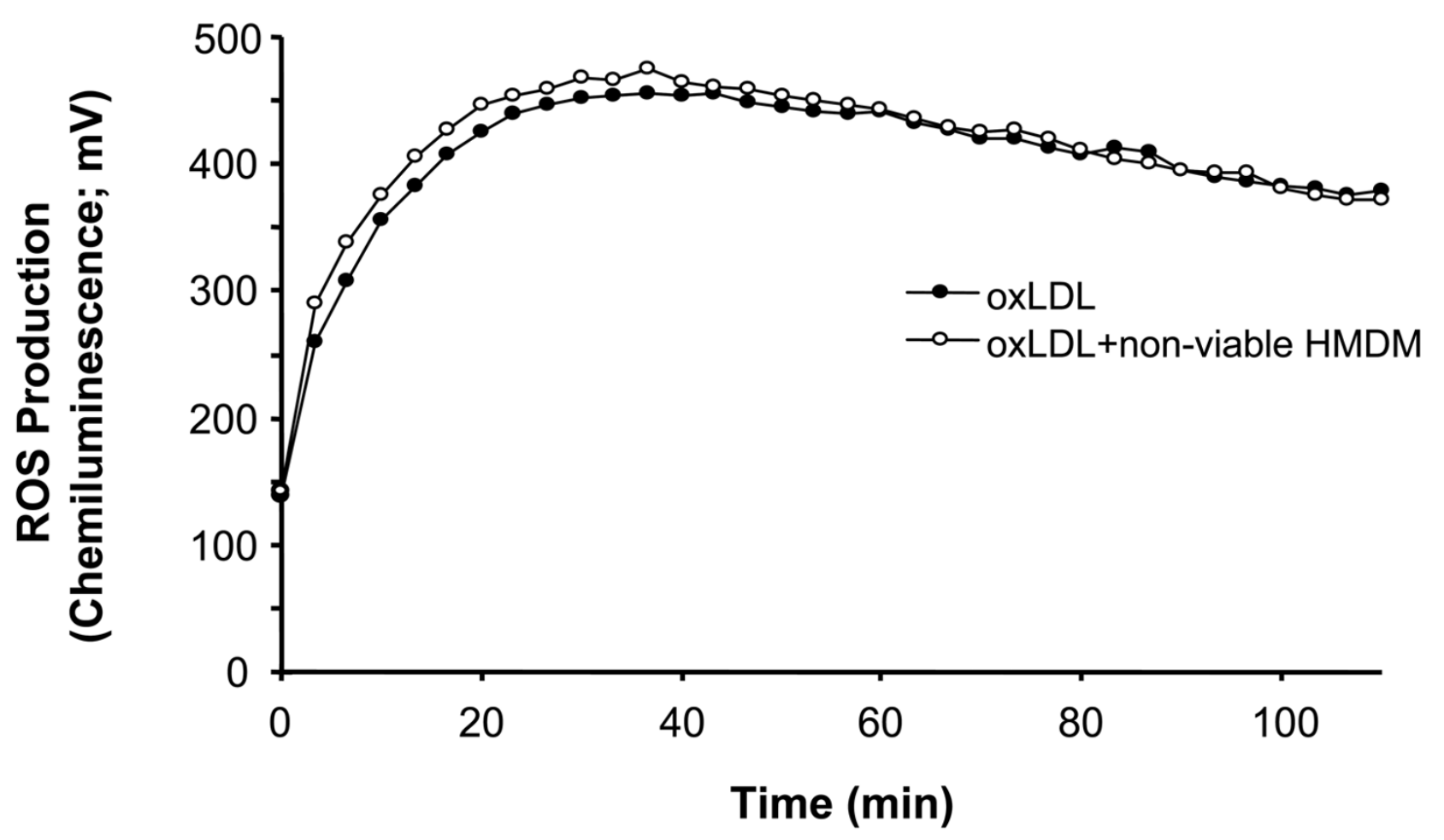

Figure 5

Production of reactive oxygen species from oxLDL and non-viable macrophages as measured by isoluminolenhanced chemiluminescence. The incubation mixture of $1.0 \mathrm{~mL} \mathrm{KRG}$, containing $10 \mu \mathrm{g}$ isoluminol, $4 \mathrm{U}$ horseradish peroxidase, and $100 \mu \mathrm{g}$ of oxLDL (oxidized for $2 \mathrm{~h}$ ), was used alone or in combination with $5 \times 10^{5}$ non-viable macrophages. Data are shown from a typical experiment with 2 different cell donors.

evidence that lipid hydroperoxides in oxLDL induce antioxidant defences in macrophages, since human macrophages also upregulated their catalase activity. Human macrophages induce catalase activity in response to oxidative stress [34]. Addition of catalase to oxLDL alone reduced the CL response by 37\%, suggesting that peroxides are detected by the CL technique.

EC-SOD occurs in high concentration in both non-diseased [35] and atherosclerotic arterial walls [19]. In nondiseased arteries, the enzyme is primarily secreted by smooth muscle cells, whereas in atherosclerotic lesions it is also expressed by macrophages [19]. Higher levels of EC-SOD are present in cell culture media after $24 \mathrm{~h}$ than after $2 \mathrm{~h}$, but the presence of LDL or oxLDL does not effect EC-SOD expression. Similar results of EC-SOD expression have been described in human fibroblasts [36]. The expression of CuZn-SOD is neither affected by LDL, oxLDL nor time. This was not unexpected since CuZnSOD is generally regarded as a constitutively expressed enzyme. Mn-SOD activity increases with time, but there is no additive effect of LDL or oxLDL on its activity.

Cells can tolerate mild oxidative stress, which triggers the antioxidant defence system in an attempt to restore the oxidant- antioxidant balance [37]. We did not find an increase in antioxidant enzyme activity in LDL-treated macrophages, which suggests that the basal levels of catalase and GPx activity are sufficient to remove the oxidation products in LDL. In contrast, the augmented catalase and GPx activity suggests that oxLDL induces cellular adaptation when macrophages are exposed to increased oxidative stress.

This study suggests that oxidative stress induced by oxLDL could be balanced by a cellular antioxidant defence by newly recruited macrophages to sites of LDL oxidation. As oxidation of LDL is implicated in the development of atherosclerosis, and oxidation products of LDL are present in advanced atheromatous lesions, this may suggest that 

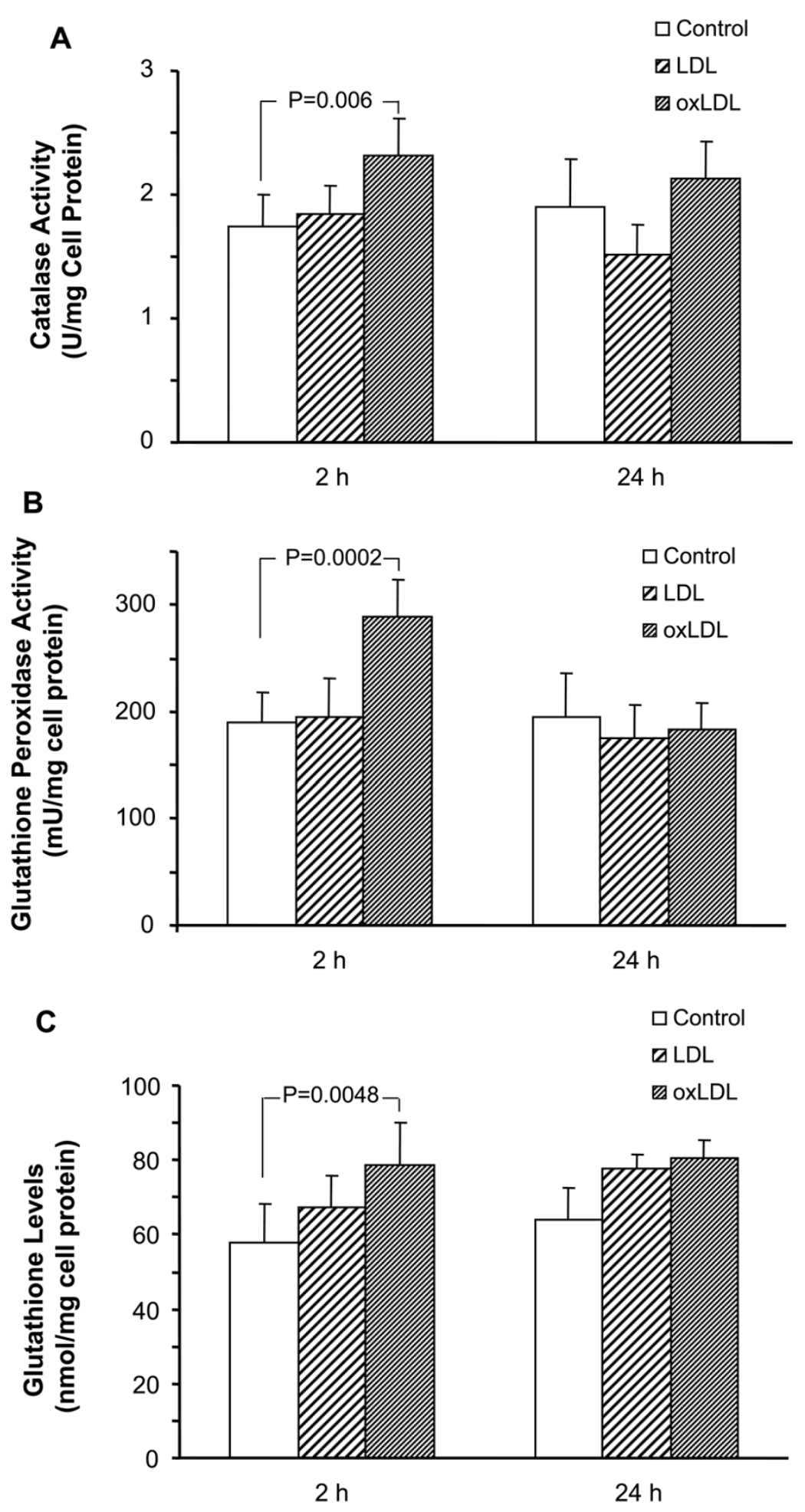

Figure 6

Effect of LDL and oxLDL on the intracellular antioxidant defenses in macrophages. The intracellular activity of catalase $(A)$, glutathione peroxidase $(B)$, and the levels of glutathione $(C)$ were measured in crude extracts from macrophages (n $=6$ ) incubated with LDL or oxLDL (oxidized for $2 \mathrm{~h}$ ). Control cells were incubated in the absence of LDL. Results were analyzed by ANOVA. 
Table I: Effect of LDL and oxLDL on superoxide dismutase isoenzymes in macrophages.

\begin{tabular}{llll}
\hline & $\begin{array}{l}\text { CuZnSOD } \\
\text { U/mg cell protein }\end{array}$ & $\begin{array}{l}\text { MnSOD } \\
\text { U/mg cell protein }\end{array}$ & $\begin{array}{l}\text { EC-SOD } \\
\text { secreted ng/mg cell protein }\end{array}$ \\
\hline $\begin{array}{lll}\text { Control 2 h } \\
\text { LDL 2 h }\end{array}$ & $81.1 \pm 7.5$ & $8.1 \pm 0.7$ & $0.61 \pm 0.28$ \\
oxLDL 2 h & $70.9 \pm 8.1$ & $8.2 \pm 0.7$ & $0.59 \pm 0.23$ \\
& $71.8 \pm 9.0$ & $7.4 \pm 0.4$ & $0.45 \pm 0.15$ \\
Control 24 h & $79.3 \pm 12.1$ & $18.6 \pm 1.8(P=0.0016)$ & $0.86 \pm 0.35$ \\
LDL 24 h & $80.8 \pm 9.9$ & $15.4 \pm 0.7(P=0.0004)$ & $0.85 \pm 0.31$ \\
oxLDL 24 h & $91.2 \pm 20.6$ & $17.1 \pm 1.9(P=0.0025)$ & $0.80 \pm 0.30$ \\
\hline
\end{tabular}

Values are means $\pm S E(n=4)$. CuZn-SOD and Mn-SOD enzymatic activities were measured in cell lysates, and EC-SOD protein was determined in culture media. $\mathrm{P}$ values indicate the comparison between the effect of LDL/oxLDL on superoxide dismutase at $2 \mathrm{~h}$ and $24 \mathrm{~h}$.

the antioxidant activity is insufficient in vivo. Thus, it is evident that macrophages play a dual role in atherogenesis, i.e. both by promoting and limiting LDL-oxidation. It remains to be determined during which stage of lesion development these individual characteristics pertain.

A strategy to intervene with the development of atherosclerosis would be to increase the endogenous intracellular antioxidant capacity of cells, which would remove and detoxify oxidized LDL. Interestingly, recent results show that Lovastatin increases hepatic catalase activity in cholesterol-fed rabbits [38]. In light of the response-to-retention hypothesis of atherosclerosis, subendothelial retention of atherogenic LDL is the initiating event of the disease $[39,40]$. It is tempting to speculate that macrophages are present in the atherosclerotic intima because of their antioxidant activity, which detoxifies and removes cytotoxic products in the retained LDL.

\section{Authors' contributions}

All authors have contributed to the design of the study, the data analysis, and the writing of the manuscript. The final version of the manuscript has been read and approved by all authors prior to submission. Each author's specific contribution was as follows; LMH.: study design, macrophage cell culture, CL analysis, LDL treatment. C.U.: macrophage cell culture, TBARS, LPO, GpX, and catalase analyses. A.K.: data interpretation, writing, and editing. D.v.R: CL analysis. S.L.M: SOD analyses. C.D.: setting up the CL method. O.W.: study coordination and data interpretation.

\section{Acknowledgements}

We thank Emilia Markström and Sofia Martinsson for excellent technical assistance. This work was supported by grants from the Swedish HeartLung Foundation, the Swedish Research Council (grant no. 13488 to OW and grant 14816 to AK), and the Swedish Society of Medicine. Dr. David van Reyk, a visiting scientist at the Wallenberg Laboratory, Sahlgrenska University Hospital, was kindly supported by the Heart Research Institute and the Sydney Free Radical Group.

\section{References}

I. Berliner JA, Heinecke JW: The role of oxidized lipoproteins in atherogenesis. Free Radic Biol Med 1996, 20:707-727.

2. Steinberg D: Low density lipoprotein oxidation and its pathobiological significance. J Biol Chem 1997, 272:20963-20966.

3. Ross R: Atherosclerosis--an inflammatory disease. N Engl J Med 1999, 340:115-126.

4. van Reyk DM, Jessup W, Dean RT: Prooxidant and antioxidant activities of macrophages in metal-mediated LDL oxidation: the importance of metal sequestration. Arterioscler Thromb Vasc Biol 1999, 19: I I 19-I I24.

5. Baoutina A, Dean RT, Jessup W: Macrophages can decrease the level of cholesteryl ester hydroperoxides in low density lipoprotein. J Biol Chem 2000, 275:1635-1644.

6. Baoutina A, Dean RT, Jessup W: Antioxidant properties of macrophages toward low-density lipoprotein. Trends Cardiovasc Med 200I, II:I-7.

7. Smalley DM, Hogg N, Kalyanaraman B, Pritchard KA): Endothelial cells prevent accumulation of lipid hydroperoxides in lowdensity lipoprotein. Arterioscler Thromb Vasc Biol 1997, 17:3469-3474.

8. Sattler W, Stocker R: Greater selective uptake by Hep G2 cells of high-density lipoprotein cholesteryl ester hydroperoxides than of unoxidized cholesteryl esters. Biochem J 1993, 294 (Pt 3):77I-778.

9. Kinscherf R, Deigner HP, Usinger C, Pill J, Wagner M, Kamencic H, Hou D, Chen M, Schmiedt W, Schrader M, Kovacs G, Kato K, Metz $\mathrm{J}$ : Induction of mitochondrial manganese superoxide dismutase in macrophages by oxidized LDL: its relevance in atherosclerosis of humans and heritable hyperlipidemic rabbits. Faseb J 1997, II:1317-1328.

10. Meilhac O, Zhou M, Santanam N, Parthasarathy S: Lipid peroxides induce expression of catalase in cultured vascular cells. J Lipid Res 2000, 41: I 205-1213.

II. Hayes JD, McLellan LI: Glutathione and glutathione-dependent enzymes represent a co-ordinately regulated defence against oxidative stress. Free Radic Res 1999, 31:273-300.

12. Ursini F, Maiorino M, Brigelius-Flohe R, Aumann KD, Roveri A, Schomburg D, Flohe L: Diversity of glutathione peroxidases. Methods Enzymol 1995, 252:38-53.

13. Brigelius-Flohe R: Tissue-specific functions of individual glutathione peroxidases. Free Radic Biol Med 1999, 27:95I-965.

14. Thomas JP, Maiorino M, Ursini F, Girotti AW: Protective action of phospholipid hydroperoxide glutathione peroxidase against membrane-damaging lipid peroxidation. In situ reduction of phospholipid and cholesterol hydroperoxides.J Biol Chem 1990, 265:454-46I.

15. Sattler W, Maiorino M, Stocker R: Reduction of HDL- and LDLassociated cholesterylester and phospholipid hydroperoxides by phospholipid hydroperoxide glutathione peroxidase and Ebselen (PZ 5I). Arch Biochem Biophys 1994, 309:2 I4-22I.

16. Darley Usmar VM, Severn A, O'Leary VJ, Rogers M: Treatment of macrophages with oxidized low-density lipoprotein 
increases their intracellular glutathione content. Biochem J I99|, 278:429-434.

17. Sato H, Takenaka Y, Fujiwara K, Yamaguchi M, Abe K, Bannai S: Increase in cystine transport activity and glutathione level in mouse peritoneal macrophages exposed to oxidized lowdensity lipoprotein. Biochem Biophys Res Commun 1995, 215:154-159.

18. Del Boccio G, Lapenna D, Porreca E, Pennelli A, Savini F, Feliciani P, Ricci G, Cuccurullo F: Aortic antioxidant defence mechanisms: time-related changes in cholesterol-fed rabbits. Atherosclerosis 1990, 81 : 127-135.

19. Luoma JS, Stralin P, Marklund SL, Hiltunen TP, Sarkioja T, Yla-Herttuala S: Expression of extracellular SOD and iNOS in macrophages and smooth muscle cells in human and rabbit atherosclerotic lesions: colocalization with epitopes characteristic of oxidized LDL and peroxynitrite-modified proteins. Arterioscler Thromb Vasc Biol 1998, 18:157-167.

20. Boyum A: Isolation of lymphocytes, granulocytes and macrophages. Scand J Immunol 1976, Suppl 5:9-15.

21. Johansson A, Dahlgren C: Characterization of the luminolamplified light-generating reaction induced in human monocytes. J Leukoc Biol 1989, 45:444-45I.

22. Olofsson SO, Bostrom K, Svanberg U, Bondjers G: Isolation and partial characterization of a polypeptide belonging to apolipoprotein B from low-density lipoproteins of human plasma. Biochemistry 1980, 19:1059-1064.

23. Basu SK, Goldstein JL, Anderson GW, Brown MS: Degradation of cationized low density lipoprotein and regulation of cholesterol metabolism in homozygous familial hypercholesterolemia fibroblasts. Proc Natl Acad Sci U S A 1976, 73:3 I78-3 I82.

24. Yagi K: A simple fluorometric assay for lipoperoxide in blood plasma. Biochem Med 1976, 15:212-216.

25. Brigelius-Flohe R, Wingler K, Muller C: Estimation of individual types of glutathione peroxidases. Methods Enzymol 2002, 347:101-112.

26. Aebi H: Catalase in vitro. Methods Enzymol 1984, 105:12I-126.

27. Marklund SL: Spectrophotometric study of spontaneous disproportionation of superoxide anion radical sensitive direct assay for superoxide dismutase. Journal of Biological Chemistry 1976, 251:7504-7507.

28. Karlsson K, Marklund SL: Plasma clearance of human extracellular-superoxide dismutase $\mathbf{C}$ in rabbits. J Clin Invest 1988, 82:762-766.

29. Hazen SL, Hsu FF, Duffin K, Heinecke JW: Molecular chlorine generated by the myeloperoxidase-hydrogen peroxide-chloride system of phagocytes converts low density lipoprotein cholesterol into a family of chlorinated sterols. J Biol Chem 1996, 27 I :23080-23088.

30. Rydberg EK, Krettek A, Ullstrom C, Ekstrom K, Svensson PA, Carlsson LM, Jonsson-Rylander AC, Hansson GI, McPheat W, Wiklund O, Ohlsson BG, Hulten LM: Hypoxia increases LDL oxidation and expression of I5-lipoxygenase-2 in human macrophages. Arterioscler Thromb Vasc Biol 2004, 24:2040-2045.

31. Lundqvist $H$, Dahlgren $C$ : Isoluminol-enhanced chemiluminescence: a sensitive method to study the release of superoxide anion from human neutrophils. Free Radic Biol Med 1996 20:785-792

32. Esterbauer $\mathrm{H}$, Gebicki J, Puhl H, Jurgens $\mathrm{G}$ : The role of lipid peroxidation and antioxidants in oxidative modification of LDL. Free Radic Biol Med 1992, I3:341-390.

33. Brigelius-Flohe R, Maurer S, Lotzer K, Bol G, Kallionpaa H, Lehtolainen $\mathrm{P}$, Viita $\mathrm{H}$, Yla-Herttuala S: Overexpression of PHGPX inhibits hydroperoxide-induced oxidation, NFkappaB activation and apoptosis and affects oxLDL-mediated proliferation of rabbit aortic smooth muscle cells. Atherosclerosis 2000 , I52:307-316.

34. Komuro I, Keicho N, Iwamoto A, Akagawa KS: Human alveolar macrophages and granulocyte-macrophage colony-stimulating factor-induced monocyte-derived macrophages are resistant to $\mathrm{H} 2 \mathrm{O} 2$ via their high basal and inducible levels of catalase activity. J Biol Chem 200I, 276:24360-24364.

35. Stralin P, Karlsson K, Johansson BO, Marklund SL: The interstitium of the human arterial wall contains very large amounts of extracellular superoxide dismutase. Arterioscler Thromb Vasc Biol 1995, I 5:2032-2036
36. Stralin P, Marklund SL: Effects of oxidative stress on expression of extracellular superoxide dismutase, $\mathrm{CuZn}$-superoxide dismutase and Mn-superoxide dismutase in human dermal fibroblasts. Biochem J 1994, 298 (Pt 2):347-352.

37. Halliwell BGJMC: Free Radicals in Biology and Medicine. Third Edition edition. Oxford, Oxford University Press; 1998.

38. Jeon SM, Bok SH, Jang MK, Lee MK, Nam KT, Park YB, Rhee SJ, Choi MS: Antioxidative activity of naringin and lovastatin in high cholesterol-fed rabbits. Life Sci 200I, 69:2855-2866.

39. Williams KJ, Tabas I: The response-to-retention hypothesis of early atherogenesis. Arterioscler Thromb Vasc Biol 1995, I 5:55 I-56 I.

40. Skalen K, Gustafsson M, Rydberg EK, Hulten LM, Wiklund O, Innerarity TL, Boren J: Subendothelial retention of atherogenic lipoproteins in early atherosclerosis. Nature 2002, 4I 7:750-754.
Publish with Bio Med Central and every scientist can read your work free of charge

"BioMed Central will be the most significant development for disseminating the results of biomedical research in our lifetime. "

Sir Paul Nurse, Cancer Research UK

Your research papers will be:

- available free of charge to the entire biomedical community

- peer reviewed and published immediately upon acceptance

- cited in PubMed and archived on PubMed Central

- yours - you keep the copyright

Submit your manuscript here:

http://www.biomedcentral.com/info/publishing_adv.asp
BioMedcentral 